Periodica Polytechnica Architecture, 51(1), pp. 31-41, 2020

\title{
Effect of Change on the Values of Two Historic Mosques in Manisa, Turkey
}

\author{
Suna Büyükkılıç Koşun", Mine Hamamcıoğlu Turan² \\ 1 Department of Architecture, Faculty of Architecture, Ondokuz Mayıs University, Güzel Sanatlar Kampüsü, Kalkancı Mahallesi, \\ 55100 ilkadım-Samsun, Turkey \\ 2 Department of Architectural Restoration, Faculty of Architecture, İzmir Institute of Technology, Gülbahçe Mahallesi, \\ 35430 Urla-izmir, Turkey \\ * Corresponding author, e-mail: sunakosun@gmail.com
}

Received: 24 December 2018, Accepted: 18 March 2020, Published online: 25 May 2020

\begin{abstract}
This study focuses on the value-change relationship in two historic mosques and presents a management framework that considers their common conservation problems. The case studies are the Haki Baba Mosque in Manisa centre and Kabasakal Mosque in Kırkağaç, Manisa; both have been recently restored. The literature review covers value and intervention concepts with literature and archive research specific to the case studies; this includes a comparative study with similar buildings together with site observations.

Urban development, neighbourhood development maps, and comparative study tables were prepared. The effects of changes stemming from disasters, interventions, planning decisions and restoration projects were evaluated concerning the accumulated values.

Conservation problems include overdevelopment and transformation of original rural sites to urban sites; alteration of earthen roofs to hipped roofs; unplanned spatial conversion and addition of architectural elements. Restoration designs giving no reference to the authentic state of the elements and spaces also mislead the observer in terms of authenticity and are insufficient in terms of the organisation of the daily life objects.

Some universal principles to guide future interventions have been developed: heritage values should be taken as an input in the preparation of development plans; illegal interventions must be avoided; restoration designs should be based on thorough investigation and fully present authentic qualities, and the organisation of daily life objects ought to be part of the restoration design problem. Conservation councils and religious foundations should also be meticulous in evaluating the consistency of intervention decisions and quality of applications.
\end{abstract}

Keywords

intervention, value, Pious Foundations, Manisa, mosque

\section{Introduction}

The management of changes and alterations of monuments necessitates an understanding of the value-change relationship. Monuments that are part of a Waqf (a charitable institution within which a property is dedicated by its owner in perpetuity for usage with a religious, charitable or social purpose), are managed by the General Directorate of Pious Foundations (GDPF / Vakıflar Genel Müdürlüğü) whose restoration budget has been increased in the last 15 years in Turkey (Ekimci, 2013; GDPF, 2009; GDPF, 2014). In parallel to the increase in the budget, the number of restoration applications has also increased. The quality of the interventions is a determining factor in the process of monument sustainability.
The value-change relationship of historic buildings is evaluated in the context of this limited study.

Within this field, Şimşek (2009) focused on the value formation process of archaeological monuments, while Gelengül Ekimci (2011) investigated the changes to the authentic schemes of Waqf originated monuments in Üsküdar. In other examples, the value-disaster relationship is the focus; Perring (2009) discussed post-war reconstruction interventions, and Jahić (2016) presented post-war changes. The value-intervention relationship is presented in some studies with Demel (1996) and Jerome (2014) discussing the theoretical framework. Van Balen (2008) proposed a method for evaluating the intervention-authenticity 
relationship, and Burke (2010) presented a method for the evaluation of tolerance for change in modern monuments.

Some studies focus on only one intervention type and evaluate their effects on values with Yüceer (2005) evaluating the exterior mass addition-value relationship in late $19^{\text {th }}$ century buildings.

This study focuses on the value-change relationship in two Waqf originated mosques in Manisa, Turkey: Haki Baba Mosque in the city centre and Kabasakal Mosque in one of its provinces.

\subsection{Study method}

Concepts related to the cultural asset values of the mosques were identified to provide accurate information on the valuable characteristics to be conserved. The history of the case study mosques was reviewed to understand their value accumulation process and show the accumulated cultural asset values before and after the intervention. Information on the buildings was obtained from the archive of the Regional Directorate of Pious Foundations (RDPF / Vakıflar Bölge Müdürlüğ̈̈), and the site survey. Similar m osques to those in the study were selected for comparison to provide information on their original characteristics.

Urban development maps, neighbourhood development maps, and comparative study tables were prepared to understand the authentic state of the buildings, their sites and any changes. Current interventions on the case study mosques were displayed on the drawings showing the as-built state of the monuments after the realised interventions. The state of the interventions was indicated as a proposed intervention in the restoration project; intervention realised as proposed; intervention proposed but realised with different detail; intervention not proposed but realised and intervention proposed but not realised. The number of current interventions is determined to compare the number of interventions and to define those effective in the value changes of the case study mosques.

Finally, value-change relations were evaluated on-site building scales - and principles to guide future interventions proposed.

\subsection{Concepts related with the values and their changes}

Within the scope of this study, cultural asset values are defined in the following.

Sustaining the authentic function of a building is essential when conserving its use value. However, use value is also related to continuing the traditional function of the site and its relationship with the community.
Thus, preservation of both physical context and social context is required in terms of use value (ICOMOS, 2011).

Picturesque value refers to beauty stemming from the integrity of the natural setting with artificial components, the balance of the object-site relations, and the repetition of traditional design elements and construction techniques (ICOMOS, 2011).

Spiritual value has two dimensions: housing authentic praying rituals (UNESCO, 2008; ICOMOS Australia, 2005) and being a place of veneration (Seamon and Sowers, 2008; Norberg-Schulz, 1980; Stubbs, 2009; ICOMOS Australia, 2005).

Representing a period with its mass composition, plan type, spatial, architectural and structural elements as an integral whole make up the architectural value (ICOMOS, 2003).

Authentic value refers to the original characteristics of a historical monument; its artistic characteristics, construction techniques and materials used during its original construction (Stubbs, 2009). Sustaining the original characteristics or provision of sufficient reference is required for the continuation of authentic value.

Age value is how old a historical monument is and thus, the noble patina of age (Jokilehto, 2002) to be sustained. Related data should be continuously transmitted in order to sustain age value.

Documentary value includes all qualified contributions reflecting repair/intervention attitudes of different eras in the life span of the building (ICOMOS, 1964). In addition to this, their legibility; the transmission of their data is essential.

Within the framework of this study, interventions are defined as site and building scale interventions. Site scale interventions are the development plan; controlling the development of the site (ICOMOS, 1987) and restoration; comprehensive repair of the monument (Madran and Özgönül, 2005). Building scale interventions include the following:

- Removal - moving spatial, architectural or structural elements away from the building (ICOMOS, 1964).

- Reintegration - re-uniting the wholeness of an element, space or mass that has lost its unity (Croci, 1998).

- Alteration - changing the present material, form and construction technique of an element (ICOMOS, 1999).

- Renewal - changing an element with a new one (ICOMOS, 1999; Zakar and Eyüpgiller, 2015).

- Cleaning - taking layers disturbing the original characteristic away from the surface (Croci, 1998) of a building element. 
- Addition - appending elements (English Heritage, 2013) or masses to the building (Orbaşl1, 2008).

- Reinforcement - supporting an element with additional elements (Feilden, 1994).

- Presentation - providing additional elements guiding/informing people (ICOMOS Australia, 2005) to better understand the authentic state of a historical monument.

\section{Understanding Haki Baba Mosque}

History and value-change relations of Haki Baba Mosque and its site are introduced in Section 2.

\subsection{Historical background}

Manisa, bordered by Spil mountain from the south, is located on the Gediz plain (Karakuyu, 2005). The area was first settled in 2000 BC (Acun, 1999). The Türkmens occupied it in 1280; then by the Saruhanoğulları Principality in 1310, and later, the Ottoman Empire in 1415.

Linear settlement of the hill skirting Spil mountain can be seen in the Saruhanoğulları Period (Acun, 1999). The convent of Haki Baba (Acun, 1999), a Bektaşi cult member (OAPM, 2017), was to the west of the settlement, within the rural landscape. The prismatic convent mass was carved into the hill in 1371 (Kuban, 2002). It was a single-façade modest building with a prayer hall (Güvenç Duran, 2013) and a guest room (tabhane) (Altun, 1992) oriented to its courtyard, and a vista of the surroundings (Fig. 1). This additive spatial composition was typical of the era (Fig. 1). The presence of a raised platform (seki) and niches support the original function of spaces (Fig. 2) (Wikiwand, 2011). The mudbrick masonry walls (Tuztaşı and Çobancaoğlu, 2006; Acar Bilgin, 2017; Kafesçioğlu et al., 2017) with timber lintels (Fig. 3) were spanned by an earthen roof (Bulut, 2016), of which projected portions were supported with wooden posts (RDPF, 2012), as revealed in old photographs (Fig. 4). The information covering the lost details of the building

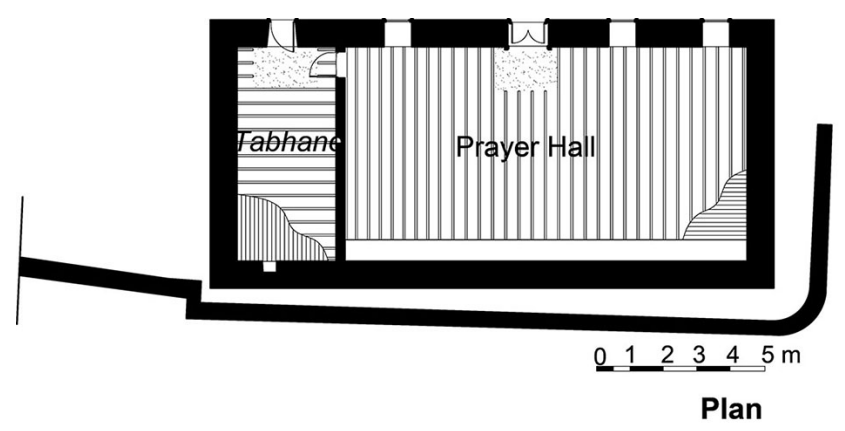

Fig. 1 Plan of Haki Baba Zaviye, restitution

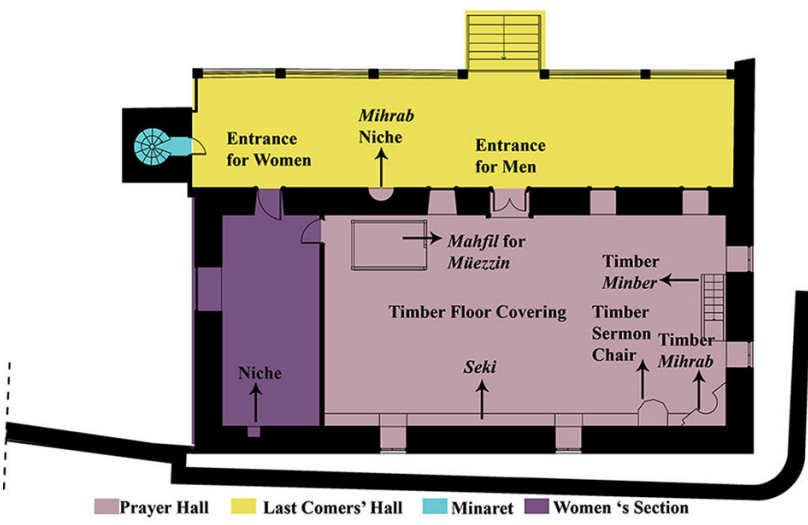

Fig. 2 As-built plan of Haki Baba Mosque

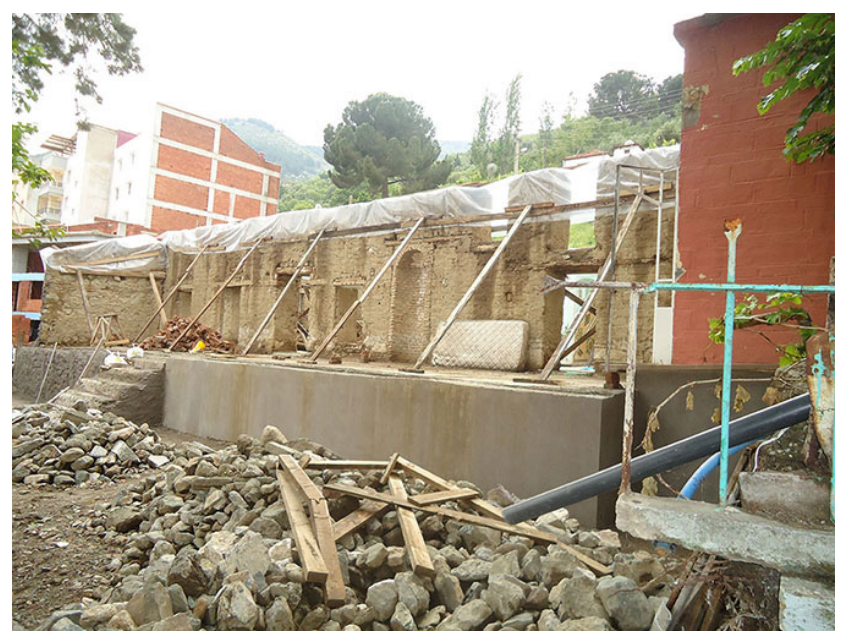

Fig. 3 Adobe mud-brick masonry walls with timber lintels, Haki Baba Mosque, during the 2014 restoration application

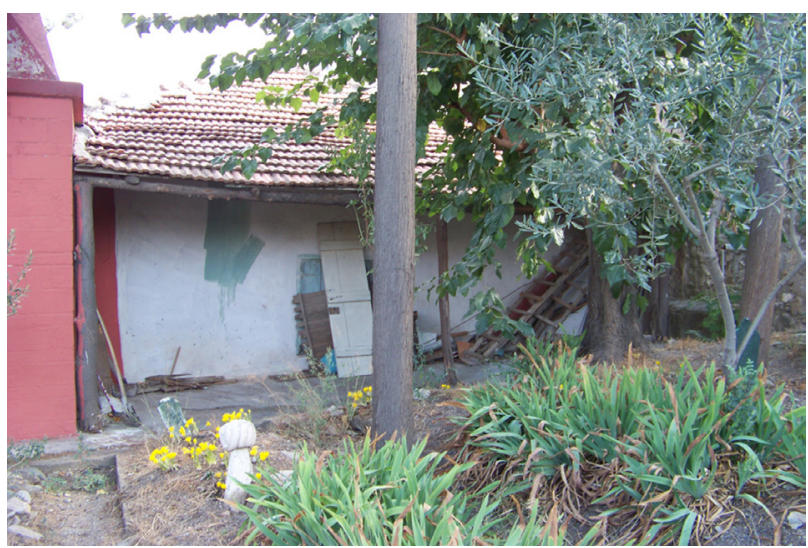

Fig. 4 Timber post remains under the eave, before restoration

was reinstated with a comparative study; for example, the earthen floor covering at the pabuçluk (entrance space for taking shoes off), a timber floor covering the rest of the floor, and a semi-circular planned mihrab niche embedded in the wall were proposed for reinstating as per the original architectural organisation. 
The case study building was initially used as a masjid from 1651-1652 (Gökçen, 1950) (Fig. 5 (a)). With the establishment of a neighbourhood in the vicinity, a route to the south of the building and a courtyard to the north were formed; access to the courtyard was from the east. Evliya Çelebi described the masjid with a hipped roof in 1671 (Dağlı et al., 2005). It is understood that the site of the masjid was damaged by magnitude seven Richter Scale earthquakes, centred around Turgutlu and Menemen districts, in 1862 and 1880 respectively (BUKOERIRETMC, 2018).

In 1871, the fountain of Serseri Dede was constructed towards the north of the courtyard entrance (Uluçay, 1940) (Fig. 5 (b)). The residential area around the masjid was damaged by fire in 1922 (Emecen, 2003).

Before 1940, the masjid was repaired; its floor was covered with quadrilateral bricks (Uluçay, 1940). The additional latecomers' portico had a lean-to roof supported with timber posts on the courtyard side. This addition resulted in the removal of the original timber posts supporting the roof on the courtyard side. An imam room and a mihrab were added to the latecomers' portico, and a window with upper and lower registers on the northern wall was converted into a mihrab niche. A simple mihrab with carved cupboards on both sides was added to the prayer hall.

Conversion of the masjid into the mosque was realised in 1956, and a minaret was added (Fig. 5 (b)) (Acun, 1999). The prayer hall was also exposed to some interventions in this period: a concrete minber addition and new voids were added to the exterior walls.

The vicinity of the monument was filled with three to five-storied buildings with the application of the 1962 Development Plan (RDPF, 2016) (Fig. 5 (c) and Fig. 6). The courtyard walls were constructed along the designated boundary of the mosque's plot. Access from the north was provided with the addition of a flight of stairs.

In the second half of the $20^{\text {th }}$ century, a new şadirvan, reservoir and toilet were added to the courtyard (Fig. 5 (d)) (RDPF, 2008). The courtyard was also entered from the west; from a partially collapsed section of the courtyard wall. A single, hipped roof was constructed to span both the prayer spaces and the latecomers' portico. Walls were rendered with cement, and the floors were covered with screed.

In the 2014 restoration (Fig. 7), removal or alteration of some mass additions disturbing the original solid-void balance of the mosque and its courtyard were realised; but the latecomers' portico was left, despite its size hiding the original entrance facade. Inappropriate interventions such as unnecessary alteration of some courtyard elements
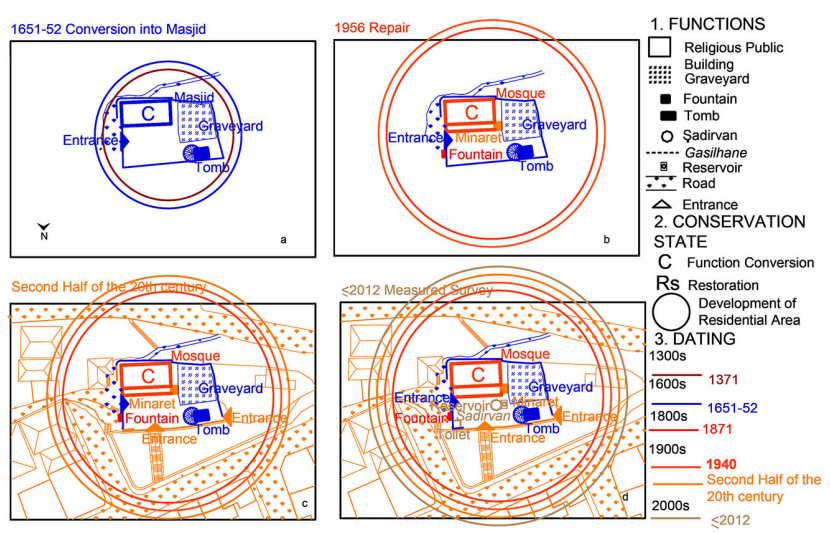

Fig. 5 Historical development of Kaynak Neighbourhood (a) 1651-52, (b) 1956, (c) second half of the 20th century, (d) $\leq 2012$ ).

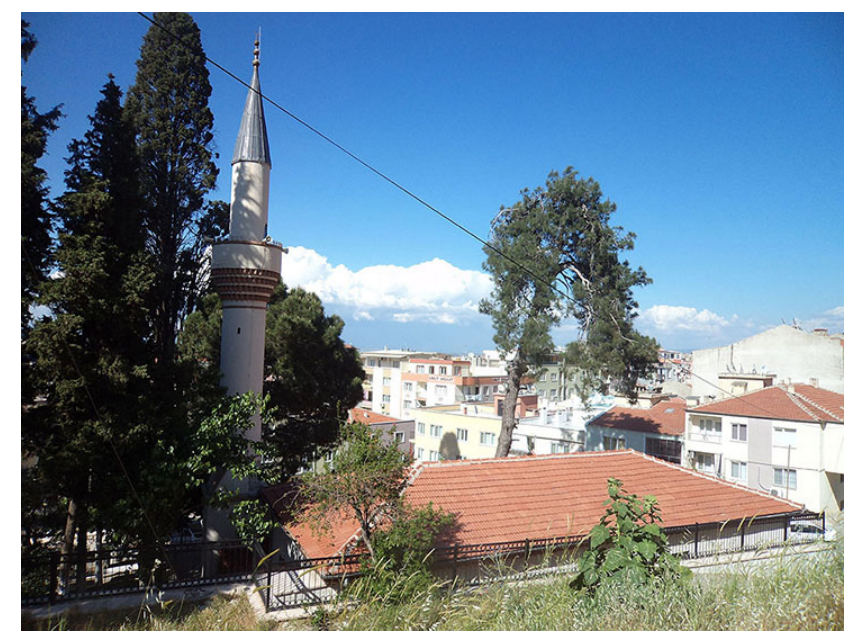

Fig. 6 Haki Baba Mosque and apartment blocks around it view from the south

of questionable design and unnecessary or disorganised additions were carried out. In addition, the renewal of authentic elements that had not deteriorated, alteration of the authentic elements, and reinforcement of the walls using building techniques of the late $19^{\text {th }}$ century also occurred. In 2015 (Fig. 8), after the approval of the restoration implementation by the related Conservation Board, the latecomers' portico was closed with glass screens with the money collected from the community by the imam.

\subsection{Value-intervention relations in Haki Baba Mosque}

Conversion of the rural site into a dense urban site has harmed the picturesque value of the modestly scaled monument built for seclusion. Natural disasters have several times, demolished this urbanised area. However, the urban site was renewed on each occasion. The urban layout hinders the picturesque value together with the disproportionately sized minaret and latecomers' portico additions to 

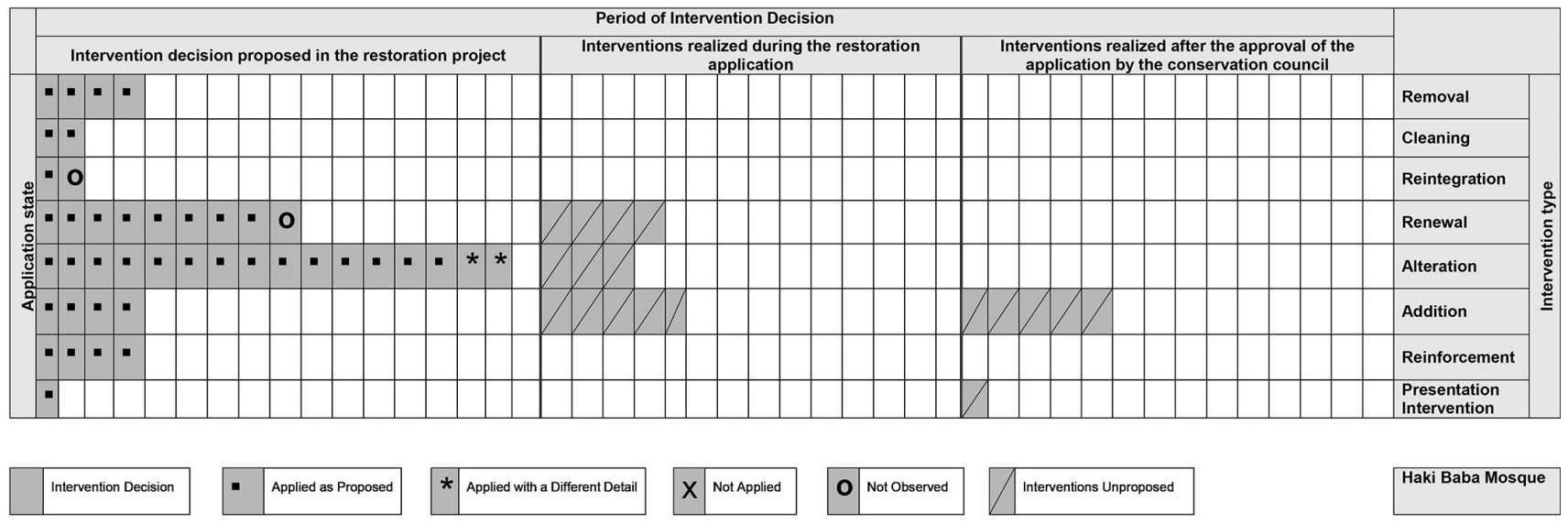

Haki Baba Mosque

Fig. 7 Realisation of intervention decisions at Haki Baba Mosque

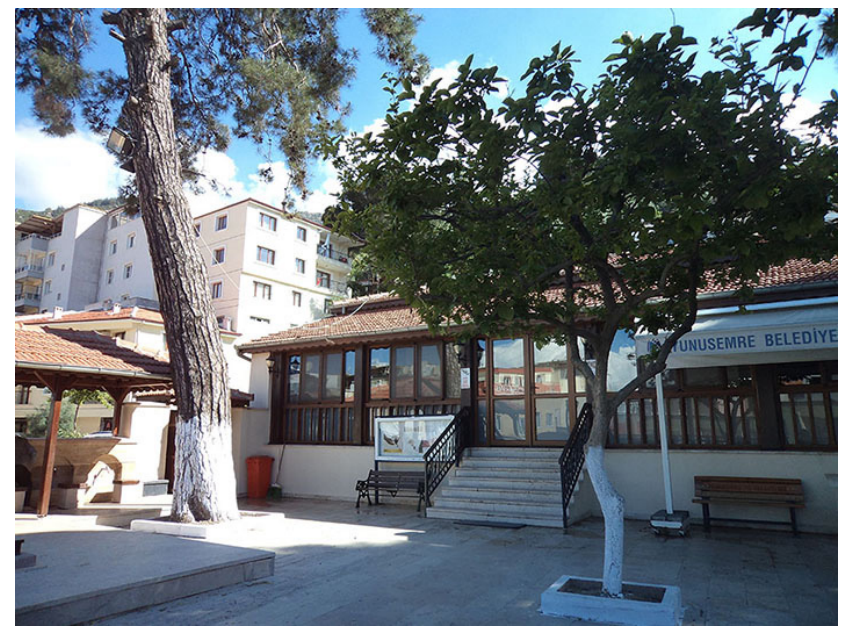

Fig. 8 Haki Baba Mosque, courtyard façade, view from the north

the mosque (Fig. 8). The spiritual value has mostly been sustained throughout its lifespan since the building is used for prayer, but there is no design approach guiding visitors on the seclusive qualities of the place in its origin. The community relationship with the building in terms of its periodic maintenance, for example, maintenance of the earthen roof or mud plaster, could not be sustained; these also reduce use value.

The mud-brick masonry walls were reinforced with a timber frame system and plastered with brick lime, giving the impression that this was the original construction technique. However, the timber posts, which were part of the flat earthen roof, were removed entirely. These interventions hinder authentic, age and documentary value. Since plan characteristics, mass characteristics, façade characteristics, construction technique and material usage were all altered throughout its life span, almost all of the architectural characteristics of the 1371 period were lost; authentic value could not be sustained.
The mosque mostly lost its authentic documentary characteristics, starting with the loss of its earthen roof in the $17^{\text {th }}$ century. Removal of disproportionate additional spaces or elements disturbing the original characteristic including the imam room, timber coverings on the walls, some daily life objects and alteration of the concrete minber with timber during the 2014 restoration are appropriate interventions helping legibility of the documentary characteristics. However, alteration of the mihrab niche with a wall infill, presenting no information about the authentic earthen roof, authentic timber floor system of the building and earthen floor at the entrance also hinder the documentary value.

As a $14^{\text {th }}$ century Saruhanoğulları period building, Haki Baba Mosque is valuable in terms of its age; however, the removal of the remains of the original roof system, the renewal of plastering and addition of daily life objects has resulted in a reduction in the age value.

\section{Understanding Kabasakal Mosque}

The history and value-change relations of Kabasakal Mosque and its site are introduced in Section 3.

\subsection{Historical background}

Kırkağaç, located in the piedmont of Yunt Mountain, is a district of Manisa. The vicinity of Ören Mosque (1383) to the south was the first area settled by Türkmen Tribes (Günay, 2001). The settlement spread to the north around Sar1 Hoca Mosque (1432) in the Ottoman Period.

In the $16^{\text {th }}$ century, the settlement extended further to the north; and the Sariağa neighbourhood developed. In those years, a former mosque was built in Kabasakal's position (RDPF 2009; Günay, 2007). The rural site was composed of prairie and simple houses covered with earthen roofs, agricultural areas and a graveyard. Following 
the growth of İzmir as an international trade centre, the Armenian and Greek population had also increased in its hinterland, including Kırkağaç (Ülker, 1994). The Armenian neighbourhood of Kırkağaç was established in the vicinity of Kabasakal Mosque in the 18th century. This gave way to the development of a grid layout settlement and an increasingly more urban trend (Fig. 9). The centre of Kırkağaç continued to house Turkish people.

In 1841, the present mosque of Kabasakal was built over the ruins of the former one (Fig. 10 (a), Fig. 10 (b) and Fig. 11). Entrance to the courtyard was from the east, south and west, with the eastern part of the courtyard hosting a graveyard. A fountain was added on the roadside, adjacent to the courtyard's western wall. Kabasakal Mosque was stone masonry, covered with an earthen roof and with narrower windows, according to a comparative study carried out with vernacular structures in the Manisa region and with similar mosques dated to late $18^{\text {th }}$ and 19th centuries in Denizli, which is another historical settlement in the region (Çakmak, 1991).

The prayer hall was divided into three naves perpendicular to the qibla wall. The rectangular planned gallery, which was for the latecomers at the north of the prayer hall, was carried by timber posts (Fig. 12). This gallery was bordered from its western side with a blind wall parallel to the road. The building was without a minaret. Interior parts of the walls of the mosque were enriched with kalemişi (hand drawing and painting on building elements).

The minaret was added to the mosque in the 19th century (Fig. 10 (c)), and the Madrasah rooms were placed in the courtyard of Kabasakal mosque in 1907 (Gökmen, 2007).

The mosque mass and its minaret, madrasah rooms, graveyard and the residential area around the mosque were damaged by the Soma earthquake of 18 th November 1919 (BUKOERIRETMC, 2018). The Madrasah, graveyard and kalemişi on the interior walls were lost in this period. A hipped roof, horizontal or squarish windows and a western courtyard wall without an entrance were realised during the repair after the earthquake.

A şadırvan (Fig. 10 (d)) and a service mass to the north of the mosque were added in 1985 and 1986, respectively (RDPF, 1986). The mass addition dated to 1986 was replaced with an unplanned disproportionately large ablution space, a dining hall and an imam's house in 2005 (RDPF, 2005) (Fig. 10 (d)). This gave way to the loss of solid-void balance on the plot. The closed space of the mosque was enlarged by including the authentic gallery for the latecomers into the prayer hall (Fig. 13). The authentic mahfil for women was then carried by concrete columns,

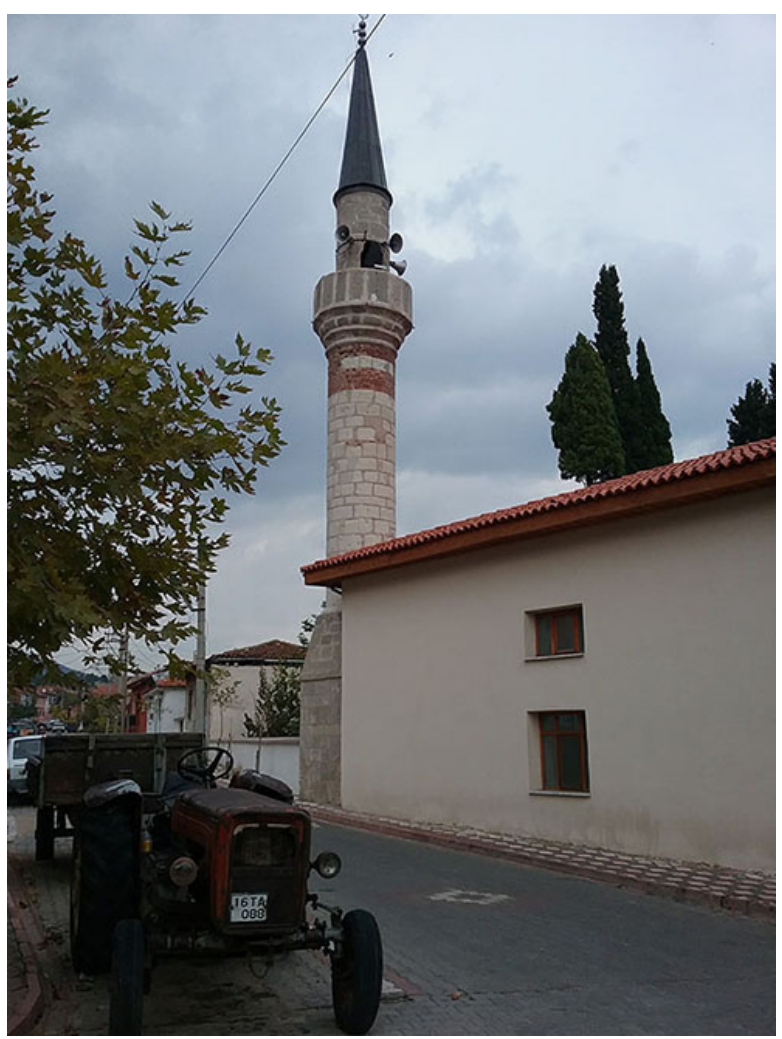

Fig. 9 Kabasakal Mosque, and road and houses surrounding it, view from the southwest

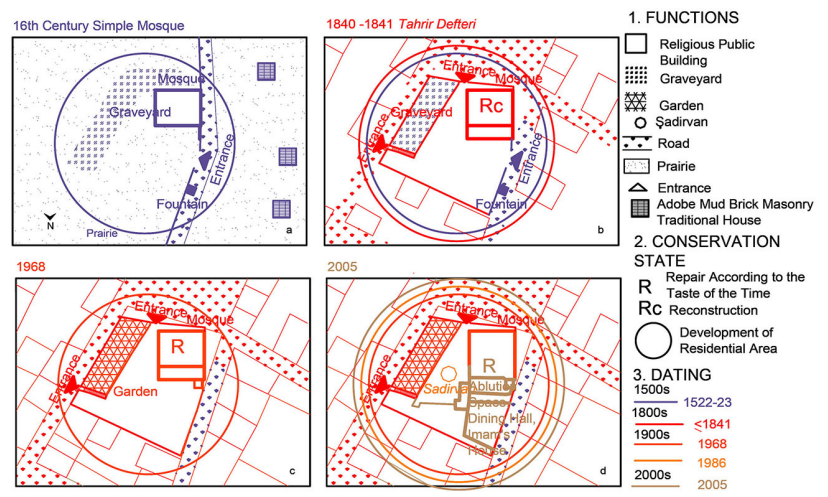

Fig. 10 Historical development of Sarıăga neighbourhood (a) 16th century, (b) 1840-41, (c) 1968, (d) 2005).

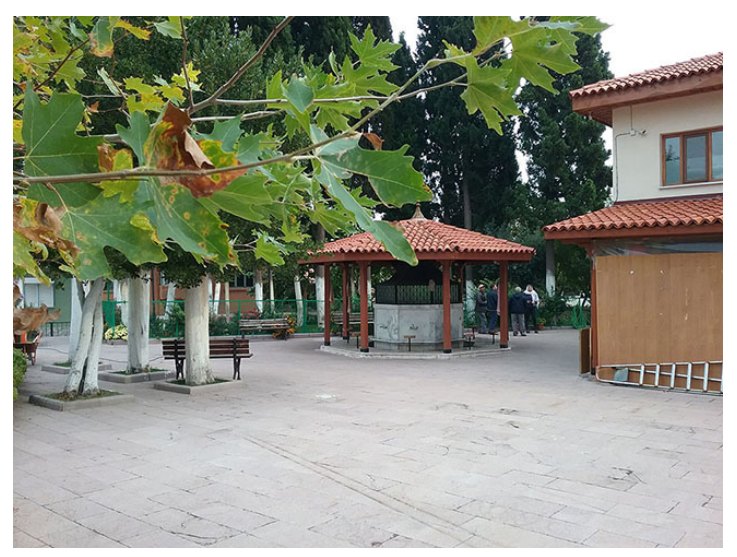

Fig. 11 Courtyard, Kabasakal Mosque, view from the northwest 


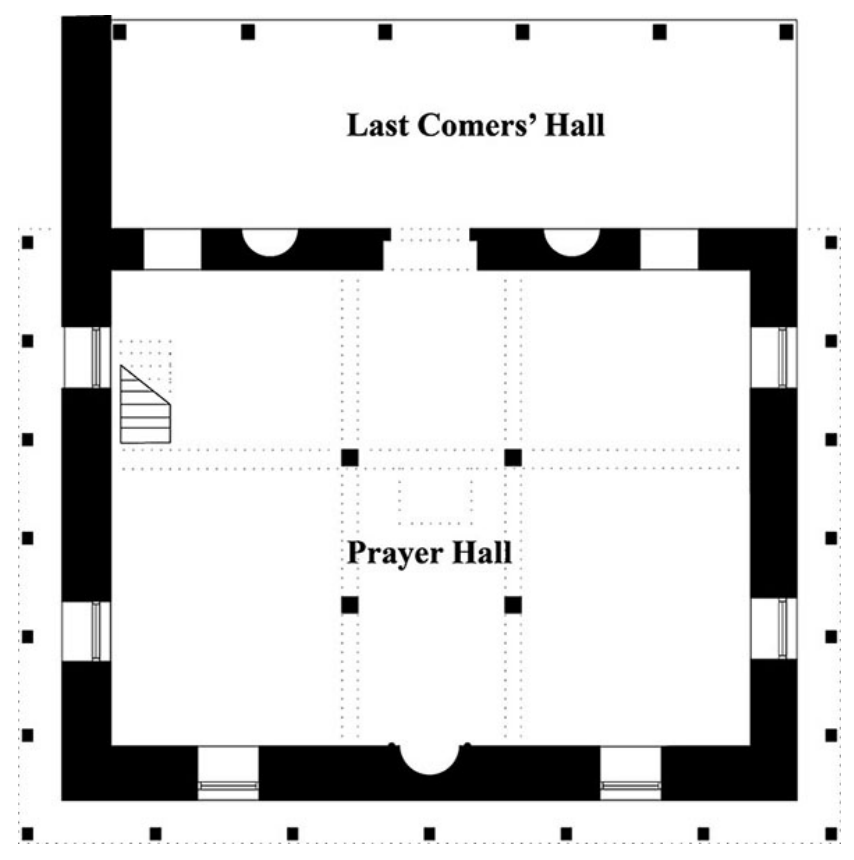

Fig. 12 Plan of Kabasakal Mosque, restitution

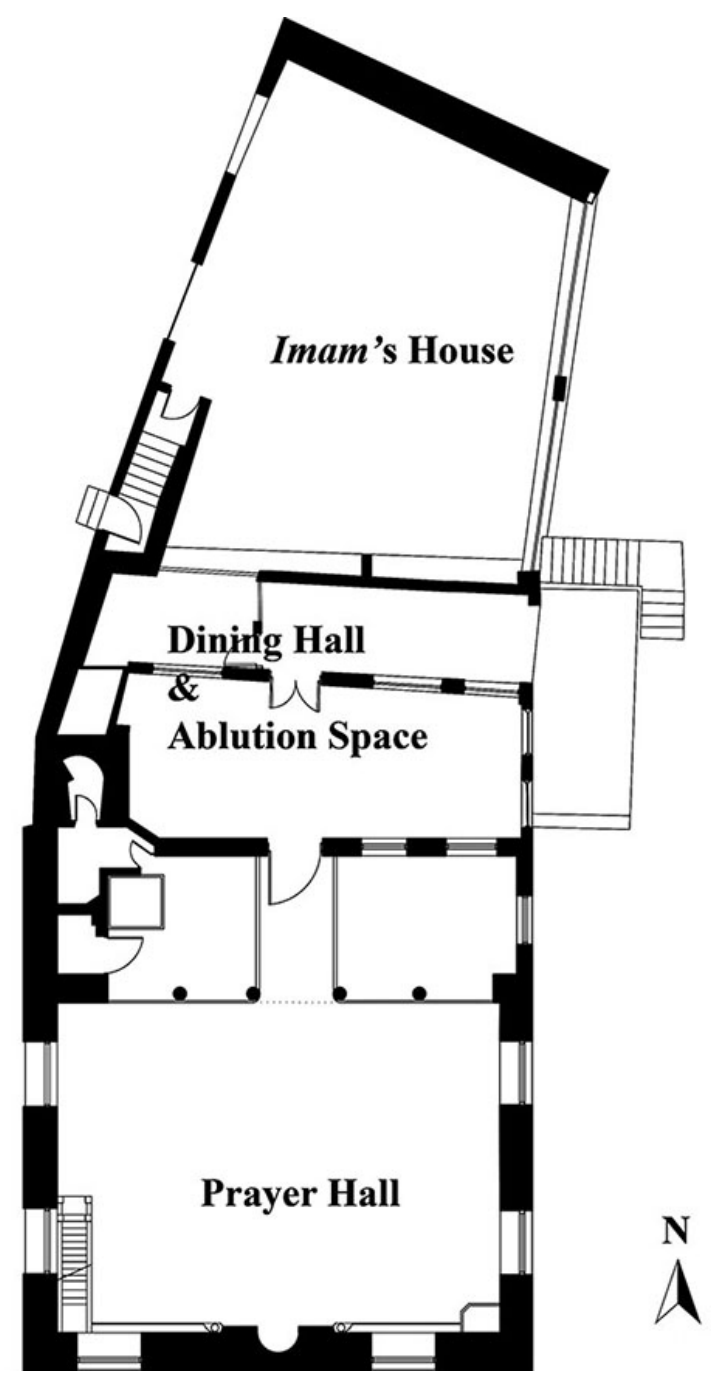

Fig. 13 Plan of Kabasakal Mosque, measured survey (Revised from RDPF, 2009)

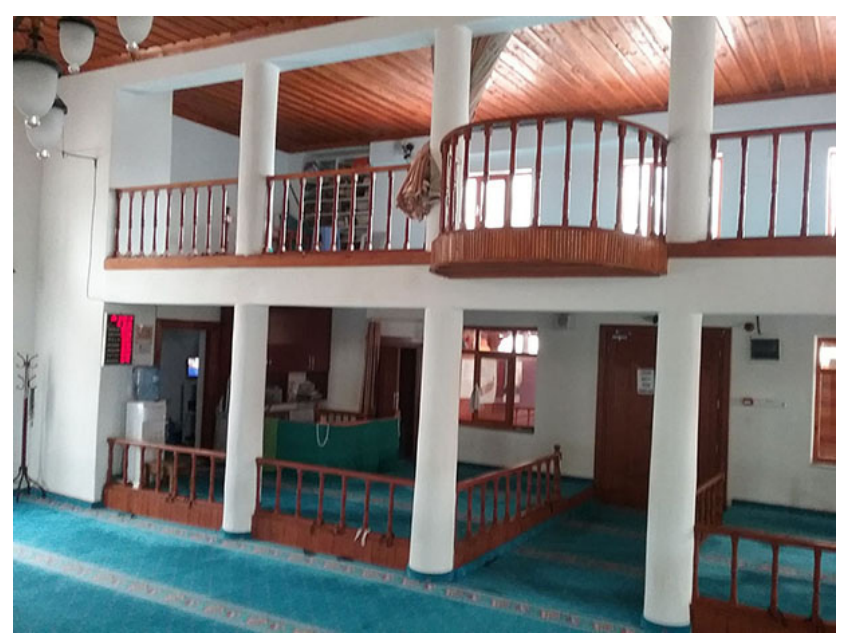

Fig. 14 Spaces and elements at the northern part of the prayer hall, Kabasakal Mosque

and additional mahfils for müezzins were provided in this enlarged part (Fig. 14). At the north-western part of the prayer hall, a stairwell replaced the stairs for the mahfil for women. The minaret was entered from the same stairwell. An imam room reached from the prayer hall with an additional door was added under the stairs. The mihrab niche was framed with marble ornamentation, and the timber minber and sermon chair were altered with marble versions.

The restoration of Kabasakal Mosque was completed in 2014 (Fig. 15 and Fig. 16). Removal of the masses added to the courtyard in 2005 was the primary positive contribution of the 2014 restoration (Fig. 17 and Fig. 18). However, sustaining the prayer hall in its enlarged form and sustaining

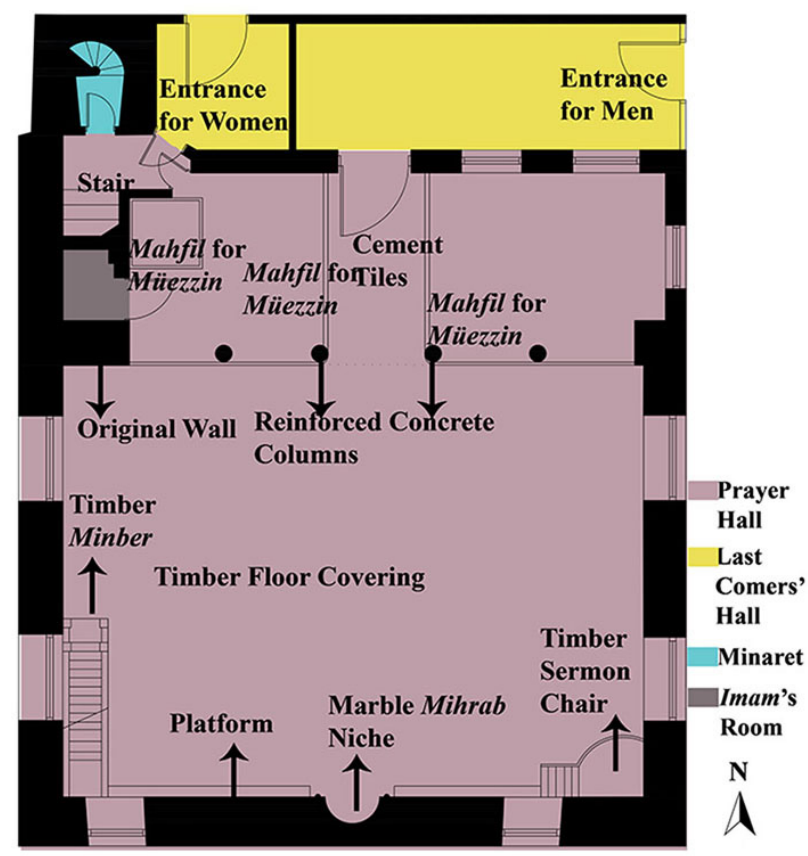

Fig. 15 As-built plan of Kabasakal Mosque 


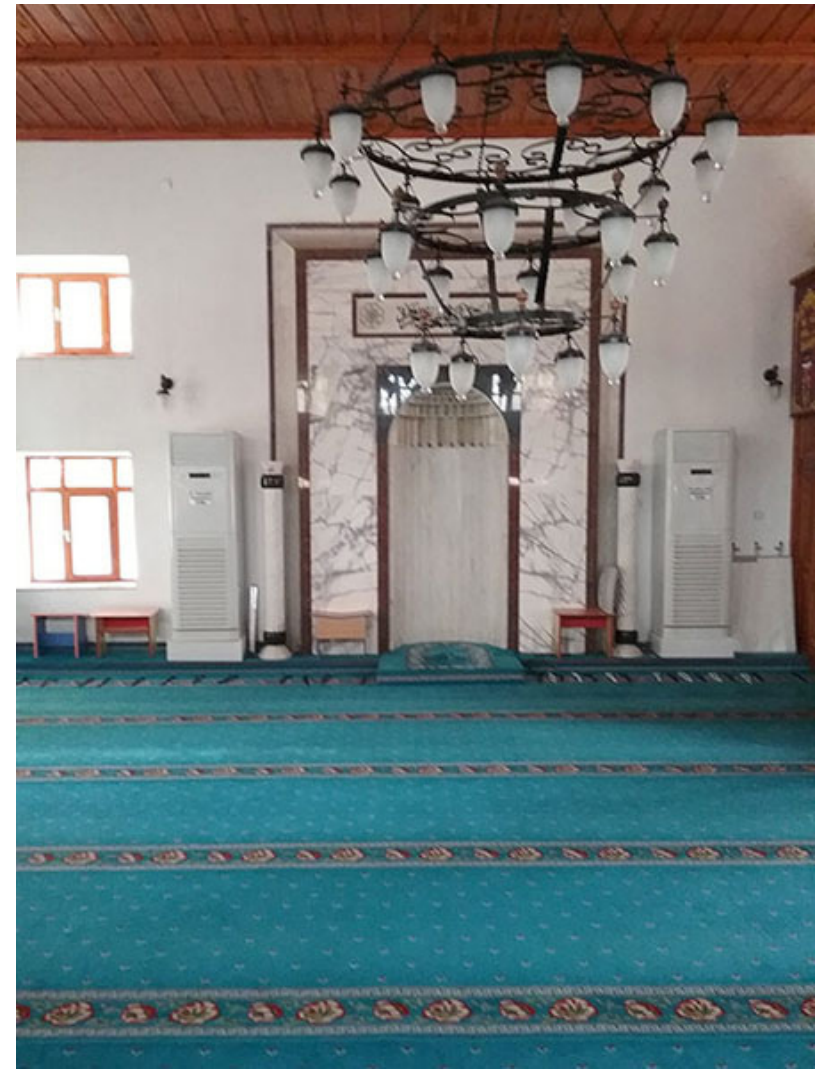

Fig. 16 New mihrab niche and air conditioners on its both sides, prayer hall, Kabasakal Mosque

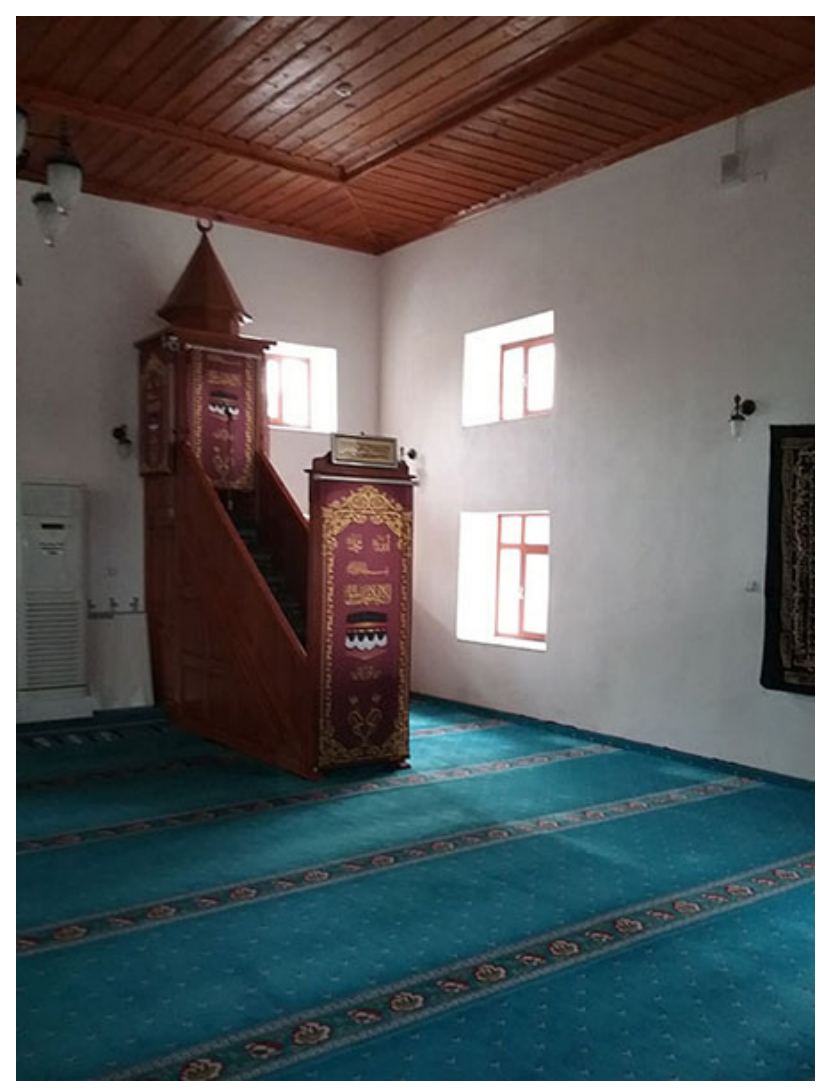

Fig. 17 New timber minber, prayer hall, Kabasakal Mosque the element alterations have harmed cultural asset values (Fig. 16). After the approval of the 2014 restoration by the related Conservation Board, an unplanned latecomers' portico disturbing the original solid-void balance of the mosque and its courtyard was added.

\subsection{Value-change relationship in Kabasakal Mosque}

The change of the authentic rural site to an urban site gave way to an irreversible conversion in the historical context. Thus, the original picturesque site, the image of a modest mosque integrated with the piedmont and rural houses in the prairie was lost. The mosque became an irregular component in the late $19^{\text {th }}$ century urban grid layout since its harmonious integration was not considered. Despite the decrease in the density of the urban site caused by the 1919 earthquake, repair of the urban site following it and the 1968 development plan negatively affected the picturesque value. This was followed by the construction of an unplanned disproportionate imam's house, ablution space and dining hall on the plot of the mosque in 2005. During the restoration work, these additions were removed, and an authentic solid-void relationship was achieved. However, changes in the social context, the need for food help and charity for inhabitants, and a request for a dining hall is another problem that requires solutions beyond the limits of architectural restoration. Lack of reference to the rural context, the original courtyard entrance, fountain and madrasah, lack of related sampling excavations during the restoration, the enlarged mass of the Mosque, and the addition of a latecomers' portico after the restoration are questionable in terms of picturesque value.

The 1919 earthquake reduced the spiritual and use values of Kabasakal Mosque; the spiritual value could not be re-established following its repair, while the use value was partially re-established. These values were further reduced in 2005 as a result of the addition of an unplanned sizeable ablution space, a dining hall and an imam's house. Use and spiritual values were re-established after their removal. Religious function and its spiritual atmosphere were purified.

The authentic value of the Mosque was damaged after the 1919 earthquake and further reduced after the 2005 interventions. The authentic artistic characteristic was a modest mass integrating with the skirting hill. This could not be totally re-established with the 2014 interventions. In addition to this, the original fenestration was not re-established in the restoration. The minaret continued to sustain its authentic value following cleaning of the plastering disturbing its original characteristic on it. 


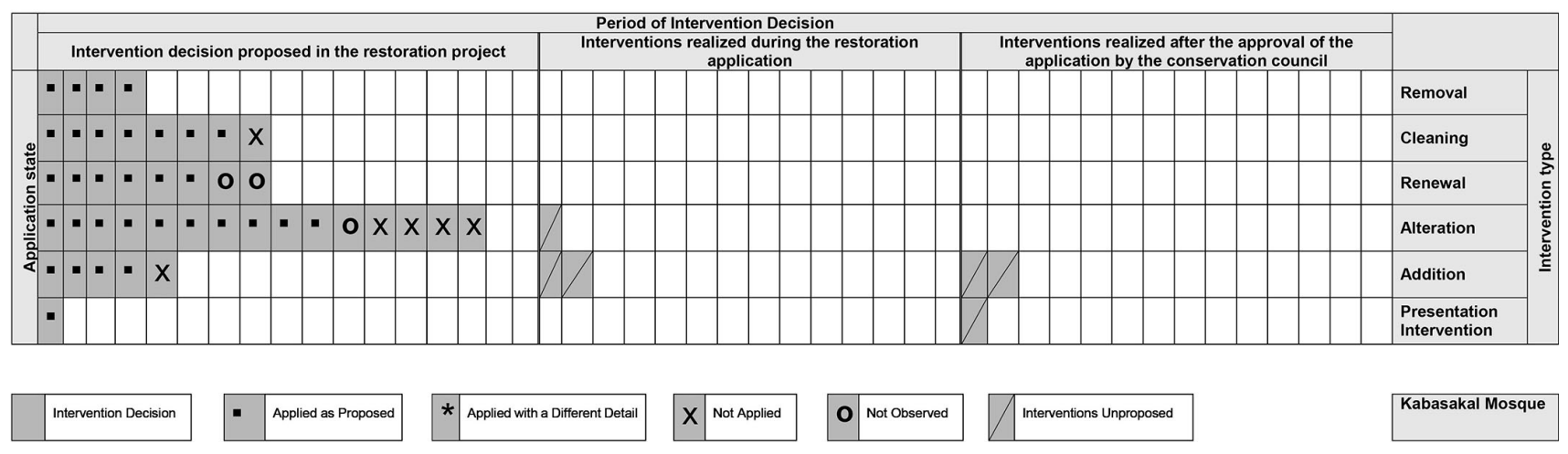

Fig. 18 Realisation of intervention decisions at Kabasakal Mosque

Maintaining the altered state of latecomers' portico included in the Mosque mass as a part of the closed space has contributed to the loss of architectural value. The original mass was further altered with the new latecomers' portico added after 2014 restoration. Addition of plastering to the authentic part of the courtyard wall, usage of eye-catching daily life objects, and addition of iron balustrades to the courtyard hinder the architectural value. Alteration of the marble minber and sermon chair with a timber one without decorative details contributes to the architectural value.

The building documents the authentic construction technique with its walls (Fig. 19) and minaret. Cleaning the plastering at the kaide, pabuç and body of the minaret, its cornice, şerefe and petek have contributed to the presentation of its authentic qualities. However; the documentary value has been hindered since its original roof, windows, and space organisation were lost.

Kabasakal Mosque, standing on the foundations of a $16^{\text {th }}$ century masjid, reflects its age with its site relations. However, apart from this, most of the noble patina of age is not preserved. Some proposed interventions such as cleaning the plastering at kaide, pabuç and body of the minaret, and some not proposed interventions; cleaning the plastering at the cornice of şerefe, şerefe and petek of the minaret make the minaret's age perceptible. The minaret sustains its age value.

\section{Discussion and conclusion}

Urbanisation gave way to the loss of the picturesque values of the case study monuments. The current interventions were mainly concerned with the removal of inadequate additions to the site. These were positive contributions to re-establish the solid-void balance, but the historical layers of the sites were not fully presented. A high number of alteration and renewal of building elements were realised (Fig. 17 and Fig. 18). These interventions are not consistent throughout the monuments. Some of them resulted

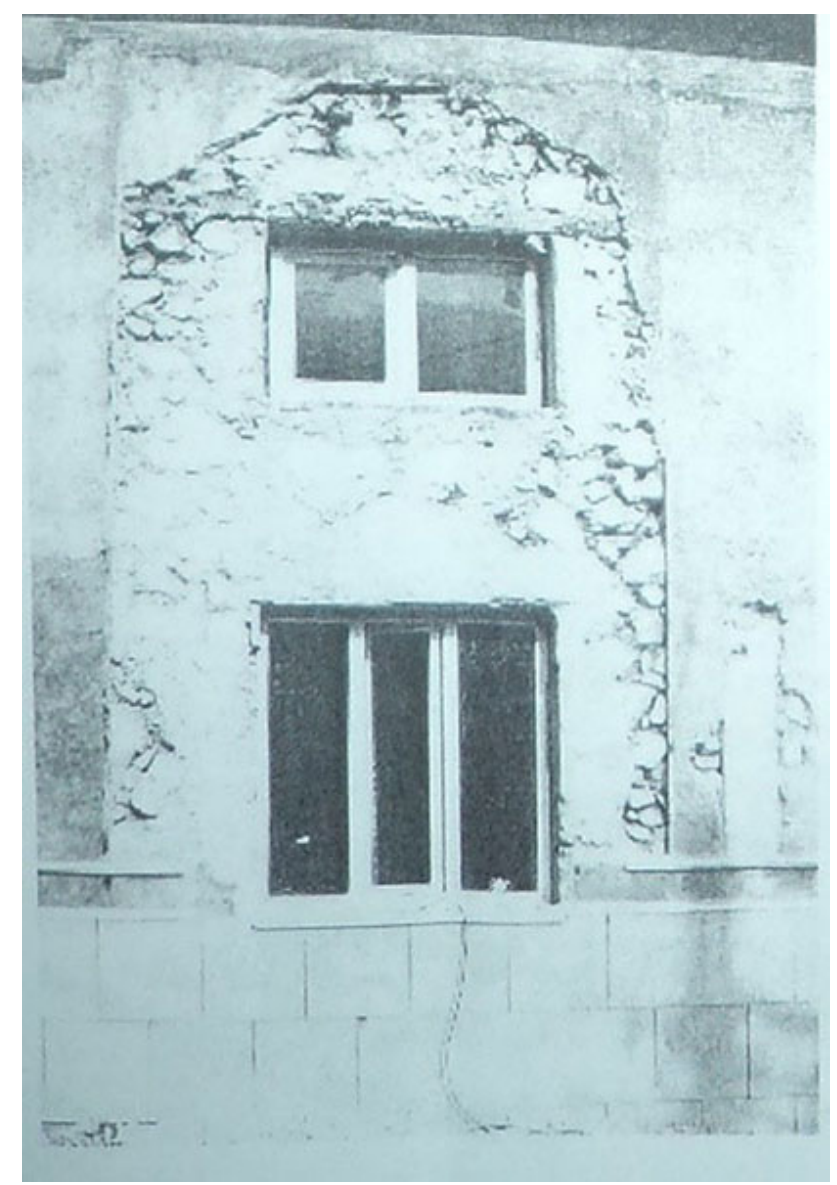

Fig. 19 Rough stone masonry wall, Kabasakal Mosque, before the 2014 restoration (RDPF, 2008)

in a loss of patina, while others led to a loss of integrity. Thus, architectural, documentary and age values could not be re-installed; moreover, age value was further lost. Additions, made immediately after the completion of the current restoration implementations, also reduced architectural and documentary values of the monuments.

Development plan decisions should sustain monument-context relation as much as possible. The Regional Directorate of Pious Foundations should participate in the preparation of the development plan process. 
Necessary control mechanisms should be provided to guarantee that the interventions regarding historical religious places are guided by restoration projects and monument management plans. Understanding the mutual relationship of authentic, physical and social characteristics of the religious building and its site is necessary for sustaining heritage values. The original spirit of the site and historical contributions to it should be presented for different user groups. The archaeological potential of the site

\section{References}

Acar Bilgin, E. (2017) "Aşağıulupınar Geleneksel Kent Dokusu ve Konutları" (City Pattern and Houses of Aşağıulupınar), In: Eyüpgiller, K. K. (ed.) Malatya/Darende Balaban ve Aşağıulupınar (Malatya/Darende Balaban and Aşağıulupınar), Babil Basım, İstanbul, Turkey, pp. 95-112. (in Turkish)

Acun, H. (1999) "Manisa'da Türk Devri Yapıları" (Turkish Period Buildings in Manisa), Türk Tarih Kurumu Basımevi, Ankara, Turkey. (in Turkish)

Altun, A. (1992) "Bulgur Tekkesi" (Bulgur Dervish Convent), In: ISAM (ed.) İslam Ansiklopedisi (Islamic Encyclopedia), Türk Diyanet Vakfi, Ankara, Turkey, 6, pp. 409. (in Turkish)

BUKOERIRETMC (2018) "Tarihsel Depremler" (Historic Earthquakes), Boğaziçi University Kandilli Observatory and Earthquake Research Institute Regional Earthquake-Tsunami Monitoring Centre, [online] Available at: http://www.koeri.boun.edu.tr/sismo/2/deprem-bilgileri/tarihsel-depremler/\# [Accessed: 29 January 2018] (in Turkish)

Bulut, İ. (2016) "Yozgat'ın Kaybolmaya Yüz Tutan Geleneksel Mesken Şekli: Karayapı" (Batal Dwelling Type in Yozgat: Karayapı), Sorgun Düşünce Kulübü [online] 13 July 2016. Available at: http:// sorgundusuncekulubu.com/?p=3507 [Accessed: 15 January 2018] (in Turkish)

Burke, S. (2010) "The long and winding road. A challenge to ICOMOS Members", In: ICOMOS Scientific Symposium Changing World, Changing Views of Heritage: The Impact of Global Change on Cultural Heritage, Dublin, Ireland, pp. 1-12. [online] Available at: https://www.icomos.org/adcom/dublin2010/Paper_3.pdf [Accessed: 16 October 2016]

Croci, G. (1998) "The Conservation and Structural Restoration of Architectural Heritage", Computational Mechanics Publication, Southampton, UK.

Çakmak, Ş. (1991) "Denizli İlindeki Türk Anıtları (Camiler)" (Turkish Monuments in Denizli City (Mosques)), Master's Thesis, Ege University. (in Turkish)

Çelebi, R. (2012) "Anadolu Kerpiç Mimarlığı" (Anatolian Adobe Mud Brick Architecture), İstanbul Kültür Üniversitesi, İstanbul, Turkey. (in Turkish)

Dağlı, Y., Kahraman S. A., Dankoff, R. (2005) "Evliya Çelebi Seyahatnamesi IX. Kitap" (Travelbook of Evliya Çelebi $9^{\text {th }}$ Book), Yapı Kredi Yayınları, İstanbul, Turkey. (in Turkish)

Demel, S. (1996) "Preservation, Historic Significance, and a Theory of Architectural Additions: The Canon and Its Consequences", Master's Thesis, Columbia University. and all qualified contributions to the monument should be considered for a consistent restoration. If mass additions are indispensable; they should be carefully designed. Contemporary interior fittings need to be considered in the restoration design.

In conclusion, improvement of the quality of restorations, in parallel to the increase in the number of applications of General Directorate of Pious Foundations is fundamental in maintaining architectural history and integrity.

Ekimci, B. (2013) "Vakıf Eserlerin Restorasyonu ve Üsküdar Selimiye Camisi" (Restoration of Waqf Origined Monuments and Üsküdar Selimiye Mosque), Mimarlık Dergisi: Journal of Architecture, 372. [online] Available at: http://www.mimarlikdergisi.com/ index.cfm?say fa $=$ mimarlik \&DergiSayi $=386 \&$ RecID $=3181$ [Accessed: 25 December 2017] (in Turkish)

Emecen, F. (2003) "Manisa", In: ISAM (ed.) İslam Ansiklopedisi (Islamic Encyclopedia), Türk Diyanet Vakfi, Ankara, Turkey, 27, pp. 577-583. (in Turkish)

English Heritage (2013) "Case Studies", In: McCaig, I. (ed.) Practical Building Conservation: Conservation Basics, Ashgate, London, UK, pp. 117-136.

Kafesçioğlu, R., Gürdal, E., Karagüler, M. E. (2017) "Kırsal Bölge Yapıları İçin Nitelikleri Geliştirilmiş Kerpiç" (Adobe with Developed Qualities for the Rural Area Buildings), In: Eyüpgiller, K. K. (ed.) Malatya/Darende Balaban ve Aşağıulupınar (Malatya/ Darende Balaban and Aşağıulupınar), Babil Basım, İstanbul, Turkey, pp. 55-71. (in Turkish)

Feilden, B. M. (1994) "Conservation of Historic Buildings", Architectural Press, Oxford, UK.

GDPF (2009) "Strategic Plan 2010-2014", General Directorate of Pious Foundations, Ankara, Turkey. [online] Available at: http://www.vgm.gov.tr/belgeler/faaliyet/VGM2010_2014SP.pdf [Accessed: 20 July 2017]

GDPF (2014) "Strategic Plan 2015-2019", General Directorate of Pious Foundations, Ankara, Turkey. [online] Available at: http://www. vgm.gov.tr/db/dosyalar/menu159.pdf [Accessed: 14 April 2017]

Gelengül Ekimci, B. (2011) "Üsküdar's Waqf Cultural Heritage and Proposals for Its Conservation", Doctoral Dissertation, İstanbul Technical University. (in Turkish)

Gökçen, İ. (1950) "Manisa Tarihinde Vakıflar ve Hayırlar II" (Waqfs and Charities in History of Manisa), Manisa Halkevi Yayınları, İstanbul, Turkey. (in Turkish)

Gökmen, E. (2007) "Kırkağaç Kazası Vakfiyeleri" (Waqf Charters of Kırkağaç District), In: Kırkağaç Socio-Economic History Symposium, Kırkağaç, Manisa, Turkey, pp. 33-55. (in Turkish)

Günay, V. (2001) "Köyden Kasabaya: Kırkağaç'ın Gelișimi (XVI. Yüzyıl)" (Development from Village to the City of Kırkağaç (16th century)), In: Centre for Implementation and Research of Turkish History and Culture of Celal Bayar University of Turkish Republic (eds.), Manisa Araştırmaları 1, Emek Matbaacılık, Manisa, Turkey, pp. 39-54. (in Turkish) 
Günay, V. (2007) "XVI. Yüzyılda Kırkağaç Kasabasının Doğuşu" (Origin of Kırkağaç Town in 16th Century), In: Kırkağaç SocioEconomic History Symposium, Kırkağaç, Manisa, Turkey, pp. 12-32. (in Turkish)

Güvenç Duran, Ş. (2013) "Akşebe Masjid in the old city of Alanya", Archilovers, [online] 17 August 2013. Available at: http://www. archilovers.com/projects/96044/aksebe-masjid-in-the-old-city-ofalanya.html [Accessed: 12 February 2018]

ICOMOS Australia (2005) "Heritage Information Series Heritage Interpretation Policy", Heritage Council of New South Wales, New South Wales, Australia, Rep. HO 05/011.

ICOMOS (1964) "International Charter for the Conservation and Restoration of Monuments and Sites (Venice Charter)", ICOMOS, Venice, Italy.

ICOMOS (1987) "Charter for the Conservation of Historic Towns and Urban Areas (Washington Charter)", ICOMOS, Washington, United States of America.

ICOMOS (1999) "Charter on the Built Vernacular Heritage", ICOMOS, Mexico City, Mexico.

ICOMOS (2003) "Principles for the Analysis, Conservation and Structural Restoration of Architectural Heritage", ICOMOS, Victoria Falls, Zimbabwe.

ICOMOS (2011) "Valletta Principles", ICOMOS, Valletta, Malta.

Jahić, A. (2016) "The Changes in Post-War Architectural Memorialization Case Study: Bosnia and Herzegovina", Master's Thesis, Bahçeşehir University.

Jerome, P. (2014) "The Values-Based Approach to Cultural-Heritage Preservation", APT Bulletin: The Journal of Preservation Technology, 45(2-3), pp. 3-8. [online] Available at: https://www. jstor.org/stable/pdf/23799521.pdf [Accessed: 27 December 2017]

Jokilehto, J. (2002) "A History of Architectural Conservation", Butterworth-Heinemann, Oxford, UK.

Karakuyu, M. (2005) "Manisa'nın Tarihi Coğrafyası" (Historic Geography of Manisa), Doctoral Dissertation, Ankara University. (in Turkish)

Kuban, D. (2002) "Selçuklu Çağında Anadolu Sanatı" (Anatolian Art in Seljukid Period), Yapı Kredi Yayınları, İstanbul, Turkey. (in Turkish)

Madran, E., Özgönül, N. (2005) "Kültürel ve Doğal Değerlerin Korunması" (Conservation of Cultural and Natural Values), Yalçın Matbaacılık, Ankara, Turkey. (in Turkish)

Norberg-Schulz, C. (1980) "Genius Loci: Towards a Phenomenology of Architecture", Rizzoli, New York, NY, USA. [online] Available at: http://home.fa.utl.pt/ al7531/pedidos/livros/Genius\%20Loci\%20 Towards $\% 20 \mathrm{a} \% 20 \mathrm{Phenomenology} \% 20$ of $\% 20$ Architecture.pdf [Accessed: 28 June 2016]

OAPM (2017) "Document showing the nomination of zaviyedar and tevliyet to Haki Baba Zaviye dated to 1800", Government Archive Ottoman Collection, 101-5026, Ottoman Archive of Prime Minister's Office, Ankara. [online] Available at: https:// katalog.devletarsivleri.gov.tr/Pages/Arama/DetayliArama.aspx [Accesed:17 May 2017]

Orbaşl1, A. (2008) "Architectural Conservation Principles and Practice", Blackwell Science, Oxford, UK.

Perring, D. (2009) "Archaeology and the Post-war Reconstruction of Beirut", Conservation and Management of Archaeological Sites, 11(3-4), pp. 296-314. https://doi.org/10.1179/175355210X12747818485529
RDPF (1986) "Drawings of the restoration project", Regional Directorate of Pious Foundations Collection, Archive of Regional Directorate of Pious Foundations, İzmir, Turkey.

RDPF (2005) "Drawings of the restoration project", Regional Directorate of Pious Foundations Collection, Archive of Regional Directorate of Pious Foundations, İzmir, Turkey.

RDPF (2008) "Drawings of the restoration project", Regional Directorate of Pious Foundations Collection, Archive of Regional Directorate of Pious Foundations, İzmir, Turkey.

RDPF (2009) "Drawings of the restoration project", Regional Directorate of Pious Foundations Collection, Archive of Regional Directorate of Pious Foundations, İzmir, Turkey.

RDPF (2012) "Drawings of the restoration project", Regional Directorate of Pious Foundations Collection, Archive of Regional Directorate of Pious Foundations, İzmir, Turkey.

RDPF (2016) "Drawings of the restoration project", Regional Directorate of Pious Foundations Collection, Archive of Regional Directorate of Pious Foundations, İzmir, Turkey.

Seamon, D., Sowers, J. (2008) "Place and Placelessness, Edward Relph", In: Hubbard, P., Kitchen, R., Vallentine, G. (eds.) Key Texts in Human Geography, Sage, London, UK, pp. 43-51.

Stubbs, J. H. (2009) "Time Honored A Global View of Architectural Conservation", John Wiley and Sons, Inc, Hoboken, NJ, USA.

Şimşek, G. (2009) "Interventions on Immovable Archaeological Heritage as a Tool for New Formation Process", Doctoral Dissertation, Middle East Technical University.

Tuztaşı, U., Çobancaoğlu, S. (2006) "Anadoluda Kerpicin Kullanım Geleneği ve Kerpiç Konut Yapım Sistemlerinin Karşılaştırılması" (Adobe Mud Brick Usage Tradition and Comparison of Construction Techniques of Adobe Mud Brick Houses in Anatolia), Tasarım+Kuram Journal, 5, pp. 95-104. [online] Available at: https:/Www.journalagent.com/tasarimkuram/pdfs/ DTJ_3_5_95_104.pdf [Accessed: 11 November 2017] (in Turkish)

Uluçay, Ç. M. (1940) "Saruhanoğulları ve Eserlerine Dair Vesikalar (733 H.-1220 H.)" (Documents on Saruhanoğulları and Their Monuments (733 A.H.-1220 A.H.)), Resimli Ay Matbaası, İstanbul, Turkey. (in Turkish)

UNESCO (2008) "Quebec Declaration", UNESCO, Quebec, Canada, Rep. activity-646-2.

Ülker, N. (1994) "İzmir Şehri Tarihi 1 Ticaret Tarihi Araştırmaları" (City History of İzmir 1 Research on Trade History), Akademi Kitabevi, İzmir, Turkey. (in Turkish)

Van Balen, K. (2008) "The Nara Grid: An Evaluation Scheme Based on the Nara Document on Authenticity", APT Bulletin: Journal of Preservation Technology, 39(2-3), pp. 39-45. [online] Available at: http://orcp.hustoj.com/wp-content/uploads/2016/01/2008-TheNara-Grid-An-Evaluation-Scheme-Based-on-the-Nara-Document-on-Authenticity.pdf [Accessed: 22 December 2017]

Wikiwand (2011) "Bektaşilik", [online] Available at: http:// www.wikiwand.com/tr/Bekta\% C 5\%9F \% C 3\% A Elik [Accessed: 15 March 2017]

Yüceer, H. (2005) "An Evaluation of Interventions in Architectural Conservation: New Exterior Additions to Historic Buildings", Doctoral Dissertation, İzmir Institute of Technology.

Zakar, L., Eyüpgiller, K. K. (2015) "Mimari Restorasyon Koruma Teknik ve Yöntemleri" (Architectural Restoration Conservation Techniques and Methods), Ömür Matbaacılık, İstanbul, Turkey. (in Turkish) 